\title{
E-beam irradiation for the control of Phytophthora nicotianae var. nicotianae in stonewool cubes
}

\author{
Magdalena Ptaszek, \\ Leszek B. Orlikowski, \\ Wojciech Migdal, \\ Urszula Gryczka
}

\begin{abstract}
Effectiveness of electron beam irradiation was evaluated against Phytophthora nicotianae var. nicotianae, the causal agent of stem base and root rot of tomato. In laboratory trials, irradiation of 7-day-old Phytophthora cultures growing on potato-dextrose-agar (PDA) medium with $1 \mathrm{kGy}$ resulted in the disintegration of the pathogen's hyphae. Increasing the irradiation dose to $3 \mathrm{kGy}$ caused decay of the hyphae. Irradiation of infested stonewool with $5 \mathrm{kGy}$ caused decrease of the pathogen population about 5 times. Application of $20 \mathrm{kGy}$ completely eliminated the pathogen from stonewool. Irradiation of substratum resulted in significant increase of tomato seedlings healthiness, especially when the dose $20 \mathrm{kGy}$ was applied.
\end{abstract}

Key words: Phytophthora nicotianae var. nicotianae $\bullet$ tomato $\bullet$ stonewoool $\bullet$ electron beam irradiation

M. Ptaszek, L. B. Orlikowski

Research Institute of Horticulture,

1/3 Konstytucji 3 Maja Str., 96-100 Skierniewice,

Poland

\author{
W. Migdał, U. Gryczka \\ Institute of Nuclear Chemistry and Technology, \\ 16 Dorodna Str., 03-195 Warsaw, Poland, \\ Tel.: +48 22863 8439, Fax: +48 22863 9935, \\ E-mail: u.gryczka@ichtj.waw.pl
}

Received: 3 November 2014

Accepted: 20 May 2015

\section{Introduction}

In opinion of Price and Maxwell [1] Phytophthora species are the most dangerous problems in hydroponic production. Among them Phytophthora nicotianae var. nicotianae Breda de Haan (=Pnn) is the pathogen of about 300 plant species [2] including tomato (Lycopersicon esculentum L.). The pathogen causes stem and root rot, thereby inducing water deficiency symptoms. Infection with the species depends primarily on the temperature, oxygen deficiency, ethylene and carbon dioxide production in the rhizoshere and a wet stem bases. Exudation of carbohydrates and aminoacids from roots or competition for assimilates between roots and shoots increases the susceptibility of plants to infection by $P n n$ [3]. The pathogen zoospores are very important because they are spread in substratum, water and nutrient solution. In recent years, Phytophthora crown and root rot of tomato have been observed with increasing frequency in Polish greenhouse crops, especially during summer period, resulting in rapid wilt and collapse of the entire plant [4]. Ioannou and Grogan [5] observed, that single preplant soil treatment with metalaxyl at dose of $2-10 \mu \mathrm{g} / \mathrm{ml}$ protected tomato from Phytophthora root rot for 
7 weeks. In authors' studies, ethazol was less effective than metalaxyl. In the production of tomato in stonewool infested by $P n n$, steaming or application of dazomet for elimination or minimization of Pnn occurrence in substratum is difficult and expensive. In such situation, searching for simply adapted and fast decontamination methods of stonewool is necessary. The above-mentioned requirements can be fulfilled by applying ionizing radiation [6]. The effectiveness of electron beam irradiation against soil-borne pathogens in horticultural substrates has already been tested with high efficacy [6-9]. There are, however, no reports of e-beam irradiation efficacy against $P$. nicotianae var. nicotiane.

In this study (1) the effectiveness of e-beam irradiation on Pnn in in vitro conditions and (2) the control of the pathogen in stonewool substratum were evaluated. Additionally, the influence of irradiated substratum on the growth of tomato (3) was observed.

\section{Materials and methods}

\section{Phytophthora nicotianae var. nicotianae culture}

A representative $\mathrm{P} 22$ isolate of the species obtained from diseased stem base of tomato cv. Admiro was used in the in vitro trial. The culture was maintained on potato-dextrose-agar medium (PDA) at $25^{\circ} \mathrm{C}$ in the dark.

\section{Irradiation}

The linear electron accelerator Elektronika 10-10 was used for irradiation [10]. The electrons energy used for irradiation of $P$. nicotianae var. nicotianae cultures as well as for stonewool substratum was $9 \mathrm{MeV}$. Four Petri dishes with Pnn cultures were packed in thin plastic bags and treated with doses in the range 1-10 kGy doses, whereas stonewool blocks naturally infested with Pnn were treated with doses from 5 to $20 \mathrm{kGy}$. To ensure uniform dose distribution in stonewool, depth-dose distribution measurements were made. A PVC dosimetric foil was placed on the surface, the bottom and within the substrate according to a defined pattern. After one-side irradiation, the dose was measured from the foil using dose reader CD-07 [11].
Influence of irradiation on the pathogen cultures development

For in vitro trials, $5 \mathrm{~mm}$ diam. plugs taken from the edge of 7-day-old culture were transferred into the centre of 90-mm Petri dishes with PDA medium. After 7 day-incubation at $25^{\circ} \mathrm{C}$ in the dark, such cultures were irradiated with doses $1,3,5$ and $10 \mathrm{kGy}$. The control sample was not treated. After $24 \mathrm{~h}$ development of cultures was observed under microscope.

\section{Effectiveness of irradiation in the control of $P$. nicotianae var. nicotianae}

Stonewool cubes taken from greenhouse with tomato showing stem base and root rot symptoms were used. In each cube, population density of the pathogen was estimated using rhododendron leaf baits cv. Nova Zembla using procedure described by Themann and Werres [12] before their irradiation and after treatment. Three and seven days after stonewool irradiation, number of Phytophthora spots on each leaf blade was counted and after that, pieces of necrotic tissues ( $3 \mathrm{~mm}$ diam.) were transferred on PDA medium and placed in laboratory incubator. After 24 and $48 \mathrm{~h}$, the plates were checked for the presence of Phytophthora colonies, which were counted on each plate. The trials were conducted in four replications (4 Petri dishes) and on each plate 20 fragments of rhododendron necrotic spot parts were placed.

\section{Influence of e-beam irradiation doses on the tomato} seedlings healthiness and growth

The tomato seeds were sown on the surface of stonewool cubes in the following arrangement: noninfested (control), infested but not treated (control infested) and irradiated with doses 5, 10, 15 and $20 \mathrm{kGy}$. During 30 days of tomato growth on greenhouse bench at temperature varying from 17 to $27^{\circ} \mathrm{C}$, number of healthy seedlings and their development was estimated. Experimental design was completely randomized with 4 replications and 25 seedlings in each replication. Trials were repeated twice at 2-week intervals.

Table 1. Relationship between irradiation doses used for treatment of stonewool cubes infested with Phytophthora nicotianae var. nicotianae, incubation time and number of necrotic spots on rhododendron baiting leaves (A) and the pathogen colonies growing on PDA (B)

\begin{tabular}{|c|c|c|c|c|}
\hline \multirow{3}{*}{ Treatments } & \multicolumn{4}{|c|}{ Days after irradiation of stonewool } \\
\hline & \multicolumn{2}{|c|}{3} & \multicolumn{2}{|c|}{7} \\
\hline & A & B & A & $\mathrm{B}$ \\
\hline Control infested nontreated & $52.3 \mathrm{c}$ & $19.5 \mathrm{~d}$ & $50.3 \mathrm{c}$ & $18.0 \mathrm{~d}$ \\
\hline $5 \mathrm{kGy}$ & $9.5 \mathrm{~b}$ & $8.0 \mathrm{c}$ & $11.0 \mathrm{~b}$ & $9.3 \mathrm{c}$ \\
\hline 10 kGy & $2.8 \mathrm{a}$ & $5.8 \mathrm{~b}$ & $3.8 \mathrm{a}$ & $5.0 \mathrm{~b}$ \\
\hline 15 kGy & $0.5 \mathrm{a}$ & $1.3 \mathrm{a}$ & $0.5 \mathrm{a}$ & $0.3 \mathrm{a}$ \\
\hline $20 \mathrm{kGy}$ & $0 \mathrm{a}$ & $0 \mathrm{a}$ & $0 \mathrm{a}$ & $0 \mathrm{a}$ \\
\hline
\end{tabular}

Note: means in columns, followed by the same letter, do not differ (5\%) acc. to Duncan's multiple range test. Means separation for each observation time. 


\section{Results}

Influence of irradiation on the development of P. nicotianae var. nicotianae

Application of irradiation already at dose of $1 \mathrm{kGy}$ resulted in the disintegration of the pathogen's hyphae. Increasing the irradiation dose to $3 \mathrm{kGy}$ caused decay of the hyphae.

\section{Effectiveness of irradiation in the control of P. nicotianae var. nicotianae}

All tested doses used for irradiation of stonewool influenced on the pathogen population density (Table 1). Treatment of substratum cubes with 5 kGy caused drastic decrease of Pnn population. Number of necrotic spots on baiting leaves in stonewool irradiated with such dose decreased approx. 5 times. Analysis of Pnn growth, after 3 days, from necrotic spots on PDA medium indicated on significant reduction of colonies number from 19.5 on control plates to 8 in substratum treated with $5 \mathrm{kGy}$. Increase of irradiation dose resulted in almost complete elimination of Pnn from the substratum cubes. The pathogen was not discovered from stonewool irradiated with $20 \mathrm{kGy}$. Similar relations were observed after 3- and 7-day incubation (Table 1).

\section{Influence of e-beam irradiation doses on the tomato seedlings healthiness and growth}

Sowing of tomato cv. Admiro seeds into disinfected stonewool cubes resulted in higher effectiveness of germination from 60 to $80 \%$ in relation to irradiation dose. Ten days after sowing, significantly more seedlings were noticed in substratum treated with 10, 15 and $20 \mathrm{kGy}$ in comparison to untreated stonewool (control infested). There were only small differences in number of healthy seedlings in the control, uninfested stonewool and substratum irradiated with $10 \mathrm{kGy}$ and higher doses after first 10 days of plant growth. Within the next 10 days of tomato growth, the lack of significant differences in the number of healthy seedlings growing in cubes irradi-

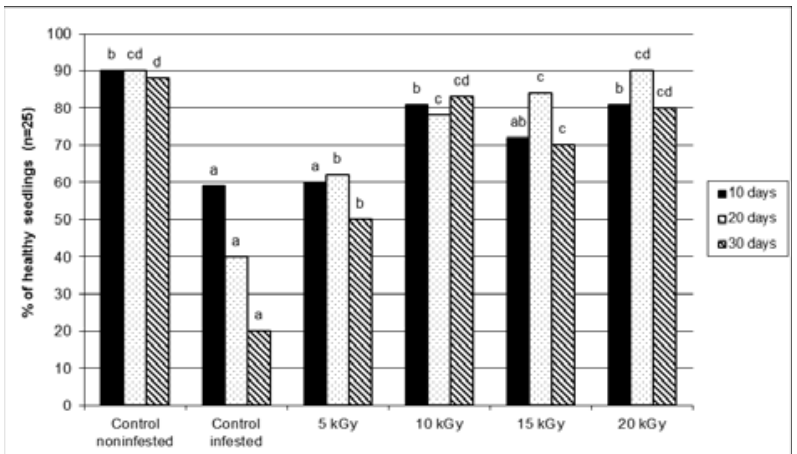

Fig. 1. Relationship between irradiation dose, growing time and healthiness of tomato seedlings.

Note: means in columns, followed by the same letter, do not differ (5\%) acc. to Duncan's multiple range test. Means separation for each observation time. ated with $20 \mathrm{kGy}$ and control, uninfested stonewool was observed (Fig. 1).

\section{Growth of tomato seedlings in relation to irradiation doses}

After 15 days of seed sowing, the significantly fastest plant growth was observed in unifested stonewool cubes compared to infested control and irradiated cubes (Fig. 2). Applying irradiation doses from 5 to $20 \mathrm{kGy}$, had no significant influence on height of plants. Increase of the growing period to 30 days resulted in similar development of control tomatoes cultivated in uninfested substratum (control) and disinfected with four irradiation doses. The seedlings from seeds sown in the infested, nontreated stonewool cubes grew very slowly (Fig. 2) and their foliage was pale green or yellow, whereas plants cultivated in irradiated substratum were dark green and had larger leaf blades.

\section{Discussion and conclusions}

Fast spread of the hydroponics in Poland was connected with the introduction in 1970 of stonewool as the substrate for the growth of vegetables under covering. Advantages of plant growth in stonewool presented by Oświecimski [13] included their better growth, higher fruit quality and increase of their healthiness. However, low diversity of antagonistic microorganisms and their small activity in stonewool do not counteract enough a contamination and spread of $P$. nicotianae var. nicotianae in such substratum $[1,14]$. In such a situation, disinfection of stonewool after growing cycle is necessary. In Ślusarski's [15] studies, paracetic acid and hydrogen peroxide were most effective in reduction of $P$. nicotianae var. nicotianae population. Both products, however, did not eliminate completly the pathogen from the substratum and growing of tomato caused a fast increase of the pathogen density by formation of zoosporangia, release of zoospores and their spread with nutrient solution. Such fast development of the pathogen caused high losses in greenhouse tomato growth [4, 15].

In this in vitro study, application of e-beam irradiation at dose of $3 \mathrm{kGy}$ caused decay of the

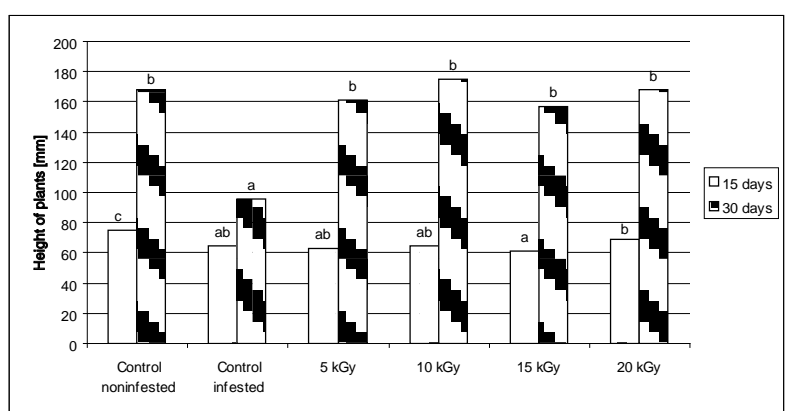

Fig. 2. Relationship between irradiation dose, growing period and development of tomato seedlings in treated stonewool. Note: means in columns, followed by the same letter, do not differ (5\%) acc. to Duncan's multiple range test. Means separation for each observation time. 
pathogen hyphae. Minimization of the pathogen occurrence was already observed in stonewool treated with $5 \mathrm{kGy}$ resulting in significant increase in the healthiness of tomato seedlings within 20-30 day growth. Results of $P$. nicotianae var. nicotianae baiting with rhododendron leaves as well as seedling test indicated on the highest irradiation efficacy at the dose of $20 \mathrm{kGy}$ for stonewool disinfection. The data obtained confirm results of previous studies with irradiation of $P$. cinnamomi cultures. Treatment of cultures growing on PDA with $1.5 \mathrm{kGy}$ resulted in hyphae disintegration and lack of chlamydospore formation, whereas at $3 \mathrm{kGy}$, decay of the pathogen was noticed [6]. Such high in vitro irradiation activity was also observed against Fusarium oxysporum f. sp. dianthi, Botrytis cinerea, P. citricola, Pythium ultimum and Rhizoctonia solani (Orlikowski et al.) [8]. Results from greenhouse trials confirm the previous trial with the control of Phytophthora species in substrata. The lack of differences between tomato healthiness growing in noninfested substratum and Phytophthora-infested stonewool irradiated with $20 \mathrm{kGy}$ in this study was connected with total elimination of P. nicotianae var. nicotianae in spite of the occurrence of large number of affected root debris.

\section{References}

1. Price, T. V., \& Maxwell, M. K. (1980). Studies of disease problems and their control in hydroponics in Australia. Acta Hortic., 98, 307-316.

2. Erwin, D. C., \& Ribeiro, O. K. (1996). Phytophthora diseases worldwide. St. Paul, Minnesota: APS Press.

3. Grote, D., \& Claussen, W. (2001). Severity of root rot on tomato plants caused by Phytophthora nicotianae under nutrient- and light-stress conditions. Plant Pathol., 50(6), 702-707.

4. Orlikowski, L. B., \& Ptaszek, M. (2014). Phytophthora nicotianae var. nicotianae on greenhouse tomatoes. Progr. Plant Protection, 54(2), 212-218 (in Polish).
5. Ioannou, N., \& Grogan, R. G. (1984). Control of Phytophthora root rot of processing tomato with ethazol and metalaxyl. Plant Disease, 68(5), 429-435.

6. Migdał, W., Orlikowski, L. B., Ptaszek, M., \& Gryczka, U. (2012). Influence of electron beam irradiation on growth of Phytophthora cinnamomi and its control in substrates. Radiat. Phys. Chem., 81(8), 1012-1016.

7. Gryczka, U., Ptaszek, M., Migdał, W., \& Orlikowski, L. B. (2010). Application of electron beam irradiation for inhibition of Fusarium oxysporum f. sp. dianthi activity. Nukleonika, 55, 359-362.

8. Orlikowski, L. B., Migdał, W., Ptaszek, M., \& Gryczka, U. (2011). Effectiveness of electron beam irradiation in the control of some soil-borne pathogens. Nukleonika, 56(4), 357-362.

9. Ptaszek, M., Gryczka, U., Migdał, W., \& Orlikowski, L. B. (2010). Application of radiation method for the elimination of Sclerotinia sclerotiorum from substrates. Zeszyty Problemowe Postęów Nauk Rolniczych, 554, 183-188 (in Polish).

10. Migdał, A., Maciszewski, W., \& Gryzłow, A. (1995). Application of ELEKTRONIKA 10-10 electron linac for food irradiation. Radiat. Phys. Chem., 46, 749-752.

11. Gryczka, U., Jakowiuk, A., Migdał, W., Kaluska, I., \& Machaj, B. (2009). Application of dose reader CD-07 for depth-dose distribution measurements in the process of microbiological radiation decontamination. Nukleonika, 54(4), 261-265.

12. Themann, K., \& Werres, S. (1998). Verwendung von Rhododendronblättern zum Nachweis von Phytophthora-Arten in Wurzel- und Bodenproben. Nachrichtenbl. Dtsch. Pflanzenschutzd., 50(2), 37-45.

13. Oświecimski, W. (1966). Current trends in the use of inorganic substrates in crops under cover. Zeszyty Problemowe Postępów Nauk Rolniczych, 429, 9-13 (in Polish).

14. Van Os, E. A., \& Postma, J. (2000). Prevention of root diseases in closed soilless growing system by microbial optimization and slow sand filtration. Acta Hort., 532, 97-102.

15. Ślusarski, Cz. (2005). Studia nad plonotwórcza efektywnościa ochrony pomidora szklarniowego przed patogenami glebowymi w wielokrotnie używanej wetnie mineralnej. Monografie i rozprawy habilitacyjne no. 20. Skierniewice: Instytut Warzywnictwa. 